\title{
Implementasi Peraturan Bupati Madiun Nomor 39 Tahun 2020 Tentang Penerapan Disiplin Dan Penegakkan Hukum Protokol Kesehatan Sebagai Upaya Pencegahan Dan Pengendalian Corona Virus Disease 2019 Di Kabupaten Madiun
}

\author{
Sarjiyati $^{1}$, Mudji Rahardjo ${ }^{2}$, Taufik Nur Pramudya Ananta ${ }^{3}$, Susani Triwahyuningsih ${ }^{4}$ \\ ${ }^{\text {I}}$ Fakultas Hukum, Universitas Merdeka Madiun, Jl. Serayu No.79, Madiun, 63133 \\ E-mail: sarajiyati@unmer-madiun.ac.id \\ ${ }^{2}$ Fakultas Hukum, Universitas Merdeka Madiun, Jl. Serayu No.79, Madiun, 63133 \\ E-mail: mudjirahardjo@unmer-madiun.ac.id \\ ${ }^{3}$ Fakultas Hukum, Universitas Merdeka Madiun, Jl. Serayu No.79, Madiun, 63133 \\ E-mail: taufiknurpramudyaananta97@gmail.com \\ ${ }^{4}$ Fakultas Hukum, Universitas PGRI Madiun, Jl. Setia Budi No.85, Madiun, 63118 \\ E-mail: susanitri@gmail.com
}

\begin{abstract}
The purpose of this study was to determine the implementation of Madiun Regent Regulation Number 39 of 2020 concerning the Implementation of Health Protocol Law Enforcement as Efforts to Prevent and Control Corona Virus Disease 2019 in Madiun Regency as well as supporting and inhibiting factors in implementing the Discipline and Law Enforcement of Health Protocols as Prevention Efforts and Corona Virus Control in Madiun Regency. In this research method, researchers use empirical, namely data obtained directly through field research with primary data sources, secondary data sources and tertiary data sources as well as data collection techniques carried out by observation, interviews, document study, to informants using descriptive data analysis techniques. qualitative. The results of this study indicate that the Regent's Regulation Number 39 of 2020 concerning the Implementation of Discipline and Law Enforcement of Health Protocols as Efforts to Prevent and Control Corona Virus Disease 2019 in Madiun Regency has been implemented quite well by the Regional Government by conducting socialization related to the application of discipline and enforcement of health protocol laws. . In implementing the Regent Regulation, there are supporting and inhibiting factors. The supporting factors are agencies that play an active role in the prevention and control of the corana virus, while the inhibiting factor is the lack of public awareness to comply with health protocols, the existence of false news (hoaxes).
\end{abstract}

Keywords—: Implementation; Regional Regulations; Corona Virus Disease 2019; Discipline Implementation and Health Protocol Law Enforcement.

\section{PENDAHULUAN}

Akhir tahun 2019 menjadi waktu yang tidak pernah di duga sebelumnya, muncul sebuah ancaman bagi kesehatan masyarakat dimana pertama kali wabah ini ditemukan di wuhan dan di beri nama corona virus disease 2019, berawal pada pada tanggal 31 Desember 2019, WHO CHINA COUNTRY OFFICE melaporkan kasus peneumonia yang tidak diketahui etiologinya di kota wuhan, provinsi hubei, china. Pada tanggal 7 januari 2020, china mengidentifikasi pneuminia yang tidak diketahui etiologinya tersebut sebagai jenis baru corona virus (coronavirus disease, covid-19).

Pada tanggal 30 Januari 2020 WHO telah menetapkan sebagai Kedaruratan Kesehatan Masyarakat Yang Meresahkan Dunia / Public Health Emergency of International Concern (KKMMD/PHEIC). Penambahan jumlah kasus COVID-19 berlangsung cukup cepat dan sudah terjadi penyebaran antar negara ${ }^{1}$. Tidak butuh waktu lama kemudian berkembang hampir ke seluruh belahan dunia sehingga Badan Kesehatan Dunia (WHO) menetapkan COVID-19 sebagai pandemi pada tanggal 11 Maret 2020. Secara resmi di Indonesia Presiden Joko Widodo menetapkan COVID-19 menjadi bencana nasional non alam pada tanggal 13 April 2020 melalui Keputusan Presiden Nomor 12 tahun 2020.

Corona virus adalah keluarga besar virus yang menyebabkan penyakit mulai dari gejala ringan sampai berat. Ada setidaknya dua jenis coronavirus yang diketahui menyebabkan penyakit yang dapat menimbulkan gejala berat seperti Middle East Respiratory Syndrome Coronavirus (MERS CoV) adalah penyakit penyakit saluran pernapasan yang disebabkan oleh coronavirus. Penyakit ini menular dari unta ke manusia, serta dari manusia ke manusia dan Severe Acute Respiratory Syndrome (SARS) adalah infeksi saluran pernapasan yang memburuk dengan cepat. Coronavirus Disease 2019 (COVID-19) adalah

${ }^{1}$ Yurianto, et el, K P 2020. PEDOMAN PENCEGAHAN DAN PENGENDALIAN CORONAVIRUS DISESASE (COVID-19). Kementerian KesehatanRI, Direktorat Jenderal Pencegahan dan Pengendalian Penyakit (P2P), Jakarta Selatan.hal,.11 
penyakit jenis baru yang belum pernah diidentifikasi sebelumnya pada manusia. Virus penyebab COVID-19 ini dinamakan Sars-CoV-2 $2^{2}$. Virus ini termasuk wabah penyakit menular yang selanjutnya disebut wabah adalah kejadian berjangkit suatu penyakit menular dalam masyarakat yang jumlah waktu dan daerah tertentu serta menimbulkan malapetaka ${ }^{3}$. Pada tanggal 2 Maret 2020, untuk pertama kalinya pemerintah mengumumkan dua kasus pasien positif COVID-19 di Indonesia ${ }^{4}$. Perkembangan kasus positif virus Corona COVID-19 di Indonesia terus mengalami penambahan pada bulan September tahun 2020 tercatat kasus Corona baru bertambah menjadi 4.071(empat ribu tujuh puluh satu) kasus. Total tercatat 252.923(dua lima puluh dua ribu, sembilan ratus dua puluh tiga) positif, 184.298 (seratus delapan empat ribu, dua ratus sembilan puluh delapan) sembuh, 9.837 (sembilan ribu delapan ratus tiga puluh tujuh) meninggal ${ }^{5}$. Dalam kasus konfirmasi COVID-19 di Indonesia tersebar dari 10 Provinsi yaitu: Bali, DKI Jakarta, Jawa Barat, Jawa Tengah, Jawa Timur, Kalimantan Selatan, Sumatera Selatan, Sumatera Utara, sulawesi selatan, Papua ${ }^{6}$.

Pemerintah Indonesia melakukan kebijakan untuk penanganan COVID-19 dengan adanya kedisiplinan dan penegakan hukum protokol kesehatan untuk mencegah terinfeksinya virus corona. Bahwa dalam rangka melaksanakan Intruksi Presiden dan Pemerintah Instruksi dari Menteri Dalam Negeri mengeluarkan kebijakan yang diatur dalam Nomor 6 Tahun 2020 tentang Peningkatan Disiplin dan Penegakan Hukum Protokol Kesehatan Dalam Pencegahan Dan Pengendalian Corona Virus Disease 2019 dan Nomor 4 Tahun 2020 tentang Pedoman Teknis Peraturan Kepala Daerah Dalam Rangka Penerapan Disiplin dan Penegakan Hukum Protokol Kesehatan Sebagai Upaya Pencegahan dan Pengendalian Corona Virus Disease 2019, maka perlu menetapkan Peraturan Bupati tentang Penerapan Disiplin dan Penegaan Hukum Protokol Kesehatan Sebagai Upaya Pencegahan dan Pengendalian Corona Virus Disease 20197 . Intruksi tersebut menunjukan bahwa penambahan COVID-19 di Indonesia semakin bertambah di berbagai wilayah Indonesia termasuk Provinsi Jawa Timur dan Kabupaten Madiun.

Menurut Pasal 1 ayat (8) Undang-Undang Nomor. 12 Tahun 2011 tentang Pembentukan Peraturan Perundang-Undangan sebagaimana diubah dengan Undang-Undang Nomor 15 Tahun 2019 tentang Perubahan Atas Undang-Undang Nomor 12 Tahun 2011 tentang Pembentukan Peraturan Perundang -undangan, Peraturan Daerah Kabupaten/Kota Merupakan peraturan perundang-undangan tingkat daerah, dibentuk oleh lembaga pemerintah di tingkat daerah dalam rangka penyelenggataan Otonom Daerah. Peraturan lainnya berupa Peraturan Kepala Daerah (Perkada), Peraturan Bersama Kepala Daerah (PB KDH) dan Keputusan Kepala Daerah ${ }^{8}$.

Berdasarkan latar belakang tersebut, maka rumusan umasalah dalam penelitian ini yaitu:

1. Bagaimana Implementasi Peraturan Bupati Nomor 39 Tahun 2020 Tentang Penerapan Disiplin Dan Penegakan Hukum Protokol Kesehatan Sebagai Upaya Pencegahan Dan Pengendalian Corona Virus Disease 2019 Di Kabupaten Madiun?

2. Apa faktor yang menjadi pendukung dan penghambat dalam Pelaksanaa Penerapan Disiplin dan Penegakan Protokol Kesehatan sebagai upaya penecegahan virus corana di Kabupaten Madiun?

\section{METODE PENELITIAN}

Penelitian hukum ini menggunakan penelitian hukum empiris penelitian yang bertitik tolak dari data primel/dasar, yakni yang di peroleh langsung dari masyarakat sebagai sumber pertama melalui penelitian lapangan, yang dilakukan melalui observasi, wawancara atau penyebar kuesioner, ${ }^{9}$ penelitian ini termasuk penelitian non doktrinal dengan analissis deskriptif kualitataif. ${ }^{10}$ lokasi penelitian ini di Kabuoaten Madiun. Teknik yang digunakan oleh penulis di dalam melakukan penentuan informan ini menggunakan purposive sampling yakni dengan pengambilan sampel sesuai dengan ciri- ciri khusus, ${ }^{11}$ Data yang digunakan dalam penelitian ini meliputi data primer, data sekunder, dan data tersier. Penggunaan data primer menunjukan bahwa penelitian ini dibangun dari fakta-fakta sosial yang terkait dengan penerapan kedisiplinan dan penegakan hukum protokol kesehatan untuk pencegahan penyebaran virus corona di Kabupaten Madiun. Data sekunder digunakan sebagai data awal yang digunakan dalam penelitian ini di antaranya Peraturan Bupati Madiun Nomor 39 Tahun 2020 Tentang Penerapan Disiplin dan Penegakan Hukum Protokol Kesehatan Sebagai Upaya Pencegahan dan Pengendalian Corona Virus Disease 2019 di Kabupaten Madiun. Data tersier yaitu rundang-undang tentang wabah peyakit menular, kesehatan dan kekarantinaan kesehatan.

\footnotetext{
${ }^{2}$ https://www.diskes.baliprov.go.id/waspadai-coronavirus-covid-19-kenali-penyebabnya-dan-lakukan-pencegahannya/. Diakses pada Selasa 8 Desember 2020 jam 08:55 WIB

${ }^{3}$ Pasal 1 huruf a Undang-Uundang Republik Indonesia Nomor 4 Tahun 1984 Tentang Wabah Penyakit Menular

${ }^{4}$ https://www.kompas.com/sains/read/2020/05/11/130600623/diumumkan-awal-maret-ahli--virus-corona-masuk-indonesia-dari-januari. Diakses pada Senin 28 September 2020 Jam 09:20 WIB

${ }^{5}$ https://majalahnurani.com/update-corona-22-september-2020-bertambah-4-071-total corona-252-923-kasus/. Diakses pada Senin 28 September 2020 Jam 10:00 WIB

6 https://www.kompas.com/tren/read/2020/07/27/162943065/lewati-100000-kasus-ini-10provinsi-dengan-infeksi-virus-corona-terbanyak?page=all. Diakses pada Senin 28 September 2020 jam 10:30 WIB.

${ }^{7}$ Menimbang Peraturan Bupati Madiun Nomor 39 Tahun 2020 Tentang Penerapan Disiplin dan Protokol Kesehatan Sebagi Upaya Pencegahan dan Pengendalian Corona Virus Disease 2019 di Kabupaten Madiun.

${ }^{8}$ Yusdiyanto,, 2012, Implementasi Kewenangan Kepala Daerah Dalam Pembuatan Perda Dan Peraturan Lainnya. Fiat Justitia Jurnal Ilmu Hukum Volume 6 No. 3 Sept.-Desember. Issn 1978-5186 Hal,.6.

${ }^{9}$ Jonaedi Efendi dan Jonny Ibrahim, 2018, Metode Penelitian Hukum Normatif dan Empiris, Prenadamedia, Depok, hal. 149.

${ }^{10}$ Lexsi J. Moleong, 2018, Metode Penelitian Kualtitatif, P.T Remaja Rordakarya, Bandung, hal. 30

11 Sugiyono, 2017, Penelitian Kuantitatif, Kualitatif, dan $R$ \& D, Alpabeta, Bandung, hal. 56.
} 


\section{III.HASIL PENELITIAN DAN PEMBAHASAN}

\section{A. Implementasi Peraturan Bupati Nomor 39 Tahun 2020 Tentang Penerapan Disiplin Dan Penegakan Hukum Protokol Kesehatan Sebagai Upaya Pencegahan Dan Pengendalian Corona Virus Disease 2019 Di Kabupaten Madiun.}

Implementasi merupakan proses umum tindakan administratif yang dapat diteliti pada tingkat program tertentu. ${ }^{12}$ Untuk mempelancar konsep implementasi kebijakan, perlu dilakukan diseminasi dengan baik. ${ }^{13}$ Pada tahap pelaksanaan dalam penerapan disiplin dan penegakan hukum protokol kesehatan Sebagaimana yang telah dipaparkan bahwa Dampak COVID-19 telah merambat ke berbagai sector, baik sector social,pendidikan terlebih pada sector ekonomi. Dampak yang meluas ke berbagai sector juga dirasakan oleh segenap masyarakat kabupaaten Madiun. Pemerintah Kabupaten Madiun telah melakukan segala upaya agar dampak COVID-19 sudah signifikan demi menyelamatkan keberlangsungan hidup masyarakatnya. Berbagai kebijakan telah dilakukan pemerintah Kabupaten Madiun dalam rangka penerapan disiplin dan penegakkan hukum protokol kesehatan sebagai upaya pencegahan dan pengendalian corona virus disease 2019. Pemerintah Kabupaten Madiun dalam pelaksanaan ini melakukan sosialisasi, monitoring dan evaluasi, sanksi yang sudah di atur dalam Peraturan Bupati Nomor 39 Tahun 2020 sebagi berikut:

\section{Sosialisasi}

Sosialisasi adalah satu konsep umum yang bisa dimaknakan sebagai sebuah proses di mana kita belajar melalui interaksi dengan orang lain, tentang cara berpikir, merasakan, dan bertindak, di mana kesemuanya itu merupakan hal-hal yang sangat penting dalam menghasilkan partisipasi sosial yang efektif. ${ }^{14}$ Untuk pelaksanaan sosialisasi terkait penerapan disiplin dan penegakan hukum protokol kesehatan pemerintah Kabupaten Madiun melakukan sosisalisasi di tempattempat wisata maupun pasar yang terdapat kerumunan masa, yang biasanya tidak melaksanakan 3M diantaranya yaitu memaskai masker, menjaga jarak, dan mencuci tangan dengan sabun dan air mengalir. ${ }^{15}$ Selain itu pada waktu kegiatan operasi sidak ataupun dalam melaksanakan pemantauhan kegiatan masyarakat pemeritah kabupaten madiun selalu memperingatkan kepada masyarakat itu sendiri untuk pelaksanaan penerapan disiplin dan protokol kesehatan untuk menghindari besarnya penyebaran virus COVID-19.

\section{Monitoring}

Dalam melaksanakan monitoring pemerintah Kabupaten Madiun sering melakukan sidak atau operasi yustisi yang tergabung dari Satpol PP Patuan Polisi Pamong Praja), BPBD (Badan Penanggulangan Bencana Daera) Kabupaten Madiun, Dinas Kasehatan, Satgas Kecamatan, Polri, TNI, Kejaksanaan, dan Pengadilan, dari segi evaluasinya melihat dari zona per kecamatan di kabupaten madiun yang sudah terpapar COVID-19 paling banyak zona merah. Jadi memusatkan kegiatan yang indikasinya daerah yang paling banyak terpapar COVID-19.16

Pada bulan Maret sampai November Tahun 2020 di Kabupaten Madiun tercatat Kasus Konsfirmasi Kasus Positif pada akhir November berjumlah 195 (seratus sembilan puluh lima) orang, sedangkan yang sembuh pada akhir November berjumlah 146 (seratus emat puluh enam) orang, meninggal pada akhir November berjumlah 10 (sepuluh) jiwa dan kasus yang masih positif tepapar COVID-19 masih di rawat di Rumah sakit pada akhir November berjumlah 116 (seratus enam belas) orang . Lebih jelasnya dapat di lihat pada berikut :

Tabel 1. Kasus Konfirmasi COVID-19 di Kabupaten Madiun Tahun 2020

\begin{tabular}{|l|l|l|l|l|l|}
\hline No & \multicolumn{1}{|c|}{ Bulan } & Positif & Sembuh & Meninggal & Dirawat \\
\hline $\mathbf{1}$ & Maret & 1 & & & 1 \\
\hline $\mathbf{2}$ & April & 3 & 2 & & 2 \\
\hline $\mathbf{3}$ & Mei & 26 & 7 & & 21 \\
\hline $\mathbf{4}$ & Juni & 5 & 21 & & 5 \\
\hline $\mathbf{5}$ & Juli & 16 & 5 & 2 & 14 \\
\hline $\mathbf{6}$ & Agustus & 27 & 23 & 2 & 11 \\
\hline $\mathbf{7}$ & September & 35 & 34 & 4 & 13 \\
\hline $\mathbf{8}$ & Oktober & 33 & 29 & 2 & 10 \\
\hline $\mathbf{9}$ & November & 39 & 25 & & 39 \\
\hline & Jumlah & 195 & 146 & 10 & 116 \\
\hline
\end{tabular}

Sumber : Dinas Kesehatan Kabupaten Madiun

\footnotetext{
12 Deddy Mulyani, 2015, Studi Kebijakan, dan Pelayanan Publik, Alfabeta, Bandung. Hal.12.

13 H. Akib dan A. Tarigan, 2008. Artikulasi Konsep Implementasi Kebijakan: Perspektif, Modal Dan Kriteria Pengukurannya, Jurnal Kebijakan Publik, akademia edu Vol. 63 No. 12.

${ }^{14}$ Joko Suyanto, 2010, Gender dan Sosialisasi, Nobel Edumedia, Jakarta, Hal 13.

${ }^{15}$ Wawancara dengan ibu Gundang Wijiastuti, S.Sos, Dinas Badan Penanggulangan Bencana Daerah Kabupaten Madiun, tanggal 4 November 2020 , pukul $10.00 \mathrm{WIB}$.

${ }^{16}$ Wawancara dengan dr. Arman Santoso, M. Kes, Dinas Kesehatan Kabupaten Madiun tanggal 9 November 2020, pukul 08.00 WIB.
} 


\section{Sanksi}

Pada tahap pelaksanaan, diadakannya penerapan displin dan penegakan hukum protokol kesehatan ini masyarakat yang melangar protokol kesehatan akan diberikan sanksi yang tidak mematuhi protokol kesehatan bagi perorangan, pelaku usaha, pengelola, penyelenggara atau penanggungjawab tempat dan fasilitas umum, penyelenggara kegiatan hajatan dan pelaku perjalanan yang melanggar kewajiban yang berupa tidak menggunakan alat pelindung diri berupa masker yang menutupi hidung dan mulut hingga dagu, tidak menyediakan sarana cuci tangan pakai sabun ynag mudah diakses dan memenuhi standar atau tidak penyediaan cairan pembersih tangan (handsanitizer) dan tidak mengatur jaga jarak, bagi pelaku perjalanan yang berasal dari wilayah/daerah zoba merah, maka wajib menunjukan Hasil Tes Rapid non reaktif atau Hasil Tes PCR Negatif.

Terkait dengan tindak pidana untuk si pelanggar maka sanksi yang dikenakan hanyalah sanksi administrasi dan tidak termasuk delik pidana. Di Kabupaten Madiun sanksi yang digunakan ada beberapa sanksi yang sifatnya alternatif karena tidak semua dikenakan sanksinya tetapi 1 (satu) sanksi ini menggugurkan sanksi yang lain contoh dari yang pertama teguran lisan dan teguran tertulis, yang kedua kerja sosial, yang ketiga penyitaan KTP yang akan tidak mendapatakan pelayanan publik. Yang ke lima yaitu denda administrasi dari masing-masing denda terdiri dari yang pertama denda Perorangan yang dikanakan denda administrasi sebesar Rp.100.000,00 (seratus ribu rupiah), yang kedua bagi pelaku usaha yang dikenakan denda administrasi sebesar Rp.250.000,00 (dua ratus lima puluh ribu rupiah), dan yang ketiga bagi pelaku Perjalanan yang dikenakan denda administrasi sebesar Rp.150.000,00 (seratus lima puluh ribu). Yang di gunakan di peraturan ini tidak adanya hukum pidana tetapi termasuk "Tipiring.

\section{B. Faktor pendukung dan penghambat dalam Pelaksanaa Penerapan Disiplin dan Penegakan Protokol Kesehatan sebagai upaya penecegahan virus corana di Kabupaten Madiun}

Dalam mengimplementasikan Peraturan Bupati Madiun Nomor 39 Tahun 2020 tentang Penerapan Disiplin dan Penegakan Hukum Protokol Kesehatan sebagai upaya pencegahan dan pengendalian corona virus disease 2019 (COVID-!)di kabupaten madiun faktor yang mempengaruhi partisipasi masyarakat dalam penerapan disiplin protokol kesehatan yang terdiri 2 (dua) yaitu:

\section{Faktor Pendukung}

Berdasarkan faktor pendukung dalam pelaksanaan penerapan disiplin dan penegakan hukum protokol kesehatan sebagai upaya pencegahan COVID-19 di Kabupaten Madiun terdapat instansi - instansi yang berperan aktif dalam pencegahan dan pengendalian virus corana ini di antaranya adalah Satuan Polisi Pamong Praja (Satpol PP), Badan Penanggulangan Bencana Daerah Kabupaten Madiun (BPBD), Dinas Kesehatan, dan Satgas COVID-19. Untuk pelaksanaan penegakkan kedisiplin dan protokol kesehatan di Kabupaten Madiun tersebut, Peraturan bupati No. 39 Tahun 2020 tentang penerapan disiplin dan penegakan hukum protokol kesehatan sesuai Intruksi Presiden No. 6 Tahun 2020. Dengan melaksanakan Operasi yustisi terkait penerapan protokol kesehatan, dilaksanakan secara gabungan diantaranya baik dari Kecamatan (Pak Camat), Satpol PP, TNI, POLRI, maupun aparat yang terkait yakni Kejaksaan dan Pengadilan, di samping itu selalu melakukan patroli untuk kerumunan masa bila mana terdapat segerombolan masa dihimbaukan untuk segera bubar dari kerumunan, dalam menangani COVID-19 pemerintah kabupaten madiun terus berupaya untuk menghimbau agar masyarakat tetap mematui penerapan disiplin dan protokol kesehatan. Pemerintah daerah Kabupaten Madiun sudah melakukan yang terbaik bagi masyarakat dalam pencegahan COVID-19 dari mulai penegakan hukum protokol kesehatan, selalu melakukan sosialisasi di masyarakat dan terbentuknya tim pengawas dan pengaman untuk pencegahan COVID-19 di Kabupaten Madiun agar terhindar dari virus yang mengakibatkan kerugian bagi individu ataupun kelompok. ${ }^{17}$

\section{Faktor Penghambat}

Adapun aktor penghambat dalam pelaksanaan pencegahan dan pengendalian COVID-19 yang dilakukan pemerintah kabupaten Madiun yaitu: masyarakat belum terbiasa dengan adanya peraturan penerapan disiplin dan penegakkan hukum pada protokol kesehatan tersebut yang menjadikan masyarakat kurang adanya kesadaran untuk mentaati protokol kesehatan yang diberlakukani. Selain itu kebiasaan masyarakat yang tidak mematuhi protokol kesehatan 3M yaitu memakai masker, menjaga jarak dan mencuci tangan ${ }^{18}$ bahkan penyebaran berita - berita yang tidak benar atau hoax di masyarakat tentang COVID-19, seperti ada yang menyebarkan informasi bahwa seseorang yang tidak terkena Covid di beritakan terkena Covid hal ini akan mengakibatkan seseorang tersebut teganggu mentalnya (psikis), menyebarkan berita - berita yang tidak benar bahkan dampak tersebut juga berpengaruh di kalangan masyarakat tentang COVID-19 sehingga dari sebagaian masyarakat yang ada tidak percaya dengan bahaya virus ini, bahkan ada yag tidak percaya dengan adanya corona virus deseae-19. ${ }^{19}$ Oleh sebab itu maka Pemerintah Kabupaten Madiun terus berupaya untuk menegakkan dan

\footnotetext{
${ }^{17}$ Wawancara dengan bapak Hariono, S.Sos. M.Si , Satgas Covi-19 Kec. Sawahan Kabupaten Madiun, tanggl 9 November 2020, pukul !4.00 WIB..

${ }^{18}$ Wawancara dengan dr. Arman Santoso, M. Kes, Dinas Kesehatan Kabupaten Madiun tanggal 9 November 2020, pukul 08.00 WIB.

${ }^{19}$ Wawancara dengan bapak Danny Yudi Satriawan, SH. M.Hum. Dinas Satuan Pilisi Pamong Praja kabupaten Madiun, tanggal 2 November 2020, pukul 11.25 WIB
} 
Website : http://yustisia.unmermadiun.ac.id/index.php/yustisia

menerapkan kebijakan bagi masyarakat yang melanggar protokol kesehatan yang sudah diatur pada Peraturan Bupati Madiun Nomor 39 Tahun 2020 yang akan di kenakan sanksi administrasi dan sosial bagi masyarakat yang melangar protokol kesehatan, hal ini di upayakan pemerintah daerah agar virus ini tidak banyak menyebar ke masyarakat yang akan mengakibatkan kerugian bagi masyarakat itu sendiri.

\section{IV.KESIMPULAN}

Berdasarkan pada pembahasan tersebut maka dapat disimpulkan bahwa:

1. Implementasi Peraturan Bupati Nomor 39 Tahun 2020 Tentang Penerapan Disiplin Dan Penegakan Hukum Protokol Kesehatan Sebagai Upaya Pencegahan Dan Pengendalian Corona Virus Disease 2019 Di Kabupaten Madiun, telah dilaksanakan dengan cukup baik oleh pemerintah kabupaten Madiun dengan melakukan sosialisasi terkait penerapan disiplin dan penegakan hukum protokol kesehatan yaitu 3M (memaskai masker, menjaga jarak, dan mencuci tangan dengan sabun dan air mengalir), sosisalisasi dilaksanakan di tempat-tempat wisata, pasar yang terdapat kerumunan masa; Melakukan monitoring dengan melakukan sidak atau operasi yustisi yang tergabung dari Satpol PP, BPBD Kabupaten Madiun, Dinas Kasehatan, Satgas Kecamatan, Polri, TNI, Kejaksanaan, dan Pengadilan; memberi sanksi kepada para yang melanggar protokol kesehatan yakni teguran lisan dan teguran tertulis, kerja sosial, penyitaan KTP denda administrasi.

2. Faktor pendukung Pelaksanaan Penerapan Disiplin dan Penegakan Protokol Kesehatan sebagai upaya penecegahan virus corana di Kabupaten Madiun karena peran aktif dari intansi Satuan Polisi Pamong Praja (Satpol PP), Badan Penanggulangan Bencana Daerah Kabupaten Madiun (BPBD), Dinas Kesehatan, dan Satgas COVID-19, adanya operasi yustisi yang dilaksanakan secara gabungan dari Kecamatan (Pak Camat), Satpol PP, TNI, POLRI, maupun dari Kejaksaan dan Pengadilan. Sedangkan faktor penghambatnya yaitu kurang adanya kesadaran masyarakat untuk mentaati protokol kesehatan, adanya berita - berita yang tidak benar (hoax).

\section{DAFTAR PUSTAKA}

\section{Buku}

Deddy Mulyani, 2015, Studi Kebijakan dan Pelayanan Publik, Bandung, Alfabeta.

Joko Suyanto, 2010, Gender dan Sosialisasi, Jakartaa, Nobel Edumedia.

Jonaedi Efendi dan Jonny Ibrahim, 2018, Metode Penelitian Hukum Normatif dan Empiris, Depok, Prenadamedia.

Lexsi J. Moleong, 2018, Metode Penelitian Kualtitatif, Bandung, P.T Remaja Rordakarya.

Sugiyono, 2017, Penelitian Kuantitatif, Kualitatif, dan $R \& D$, Bandung, Alpabeta.

Yurianto, et al, K P 2020. Pedoman Pencegahan Dan Pengendalian Coronavirus Disesase (COVID-19).Kementerian KesehatanRI,Direktorat Jenderal Pencegahan dan Pengendalian Penyakit (P2P), Jakarta Selatan.

\section{Jurnal}

H. Akib dan A. Tarigan, 2008. Artikulasi Konsep Implementasi Kebijakan: Perspektif, Modal Dan Kriteria Pengukurannya, Jurnal Kebijakan Publik, akademia edu Vol. 63 No. 12

Yusdiyanto, 2012, Implementasi Kewenangan Kepala Daerah Dalam Pembuatan Perda Dan Peraturan Lainnya. Fiat Justitia Jurnal Ilmu Hukum Volume 6 No. 3

\section{E. Peraturan Perundang-undangan}

Undang-Undang Republik Indonesia Nomor 4 Tahun 1984 Tentang Wabah Penyakit Menular.

Undang-Undang Republik Indonesia Nomor. 12 Tahun 2011 tentang Pembentukan Peraturan Perundang-Undangan sebagaimana diubah dengan UndangUndang Nomor 15 Tahun 2019 tentang Perubahan Atas Undang-Undang Nomor 12 Tahun 2011 tentang Pembentukan Peraturan Perundangng undangan.

Peraturan Bupati Madiun Nomor 39 Tahun 2020 Tentang Penerapan Disiplin Dan Penegakkan Hukum Protokol Kesehatan Sebagai Upaya Pencegahan Dan Pengendalian Corona Virus Disease 2019

\section{F. Website}

https://www.diskes.baliprov.go.id/waspadai-coronavirus-covid-19-kenali-penyebabnya-dan-lakukan-pencegahannya/. Diakses pada Selasa 8 Desember 2020 jam 08:55 WIB

https://www.kompas.com/sains/read/2020/05/11/130600623/diumumkan-awal-maret-ahli--virus-corona-masuk-indonesia-dari-januari. Diakses pada Senin 28 September 2020 Jam 09:20 WIB

https://majalahnurani.com/update-corona-22-september-2020-bertambah-4-071-total corona-252-923-kasus/. Diakses pada Senin 28 September 2020 Jam 10:00 WIB

https://www.kompas.com/tren/read/2020/07/27/162943065/lewati-100000-kasus-ini-10provinsi-dengan-infeksi-virus-corona-terbanyak?page=all. Diakses pada Senin 28 September 2020 jam 10:30 WIB 